\title{
A Research on the Mechanism of Integrating Theme Music into Ideological and Political Work in Universities
}

\author{
Wei Li, Yang Liu \\ Nanchang Institute of Science \&Technology, Nanchang, Jiangxi, 330108
}

Keywords: theme music, university, ideological and political work, integration

\begin{abstract}
Theme music is of deep historical, political, cultural and social significance. To integrate it into ideological and political work in universities is conducive to lead efficiently students to produce emotional resonance and rational reflections, which enriches the contents and forms of ideological and political education. This paper firstly discusses the importance to integrate theme music into ideological and political work in universities, then in further analyzes the predicaments confronted during the integration process, and lastly proposes several integration methods.
\end{abstract}

\section{Introduction}

The ideological and political education in universities is of important leading function for students' political quality, ideological and moral quality, legal quality, as well as the cultivation of their views on world, life and values. However, as so far, the current form of ideological and political education is single and lacking attractiveness etc which need our urgent dealing. While the integration of theme music will be able to update the contents and form because theme music is rich in emotion, history and culture whose value enable students to consider deeply views on the world, life and values and then produce good ideological and political education results. Therefore, to explore the mechanism of ideological and political education in universities is of important practical significance.

\section{Significance of Integrating Theme Music into Ideological and Political Education in Universities}

Theme music refers to songs which have positive themes and are consistent with policy as well as politics. These songs are with strong background of the times and are able to deliver positive energy. Theme music advocates the ideology and spirits of patriotism, collectivism and socialism and supports modernized as well as constructive thoughts which believe that a good life will be obtained only by our own labor. For example, songs that praise the country's prosperity, people's army as well as our happy life and carry forward Chinese dreams are all called theme music. The representatives are "Story of Spring”, "I Love You China”, "Chinese Dreams are in Your and My Hearts" and so on.

Theme music which is of historical, political, cultural and social significance, combines history, emotion, revolution history education, art education with ideological and political education, containing invisible spiritual force. Through this kind of carrier, it is possible for us to transform various resources about history, politics and arts into ideological and political education resources. Specifically, firstly, the integration of theme music into ideological and political education in universities will produce positive public opinion guidance. Through all kinds of activities carried out in universities such as theme music singing, it will construct a positive atmosphere, guiding students to insist beliefs, correct views on life and world, and then ensure the correct orientation of ideological and political education in universities. At the same time, for those students who are used to listening popular songs, application of theme music is no doubt a special form. In the views of 
contents, theme music has abundant education resources, looking forward to beautiful life with enthusiasm for nature and strong national emotions. Influenced by theme music, students tend to have emotional resonance as well as rational reflections which show theme music's subtle education results and important moral education function. Its application in ideological and political education in universities can make up for the current shortages of ideological and political education. From the term of teaching mode, theme music is also characterized by emotional, vital and vivid features whose integration into ideological and political teaching will help us discover a brand new teaching method to promote students' initiatives to participate in ideological and political activities.[1] Teaching practice proves that ideological and political work will evoke students' resonance, interests and initiatives only in ways that are easily accepted by students. Theme music has a strong emotional appeal and artistic infectivity which is easy to sing and melodious. Its application in ideological and political education which is different from traditional indoctrination teaching enables students to free their personality, emotion and imagination, improving effectively the ideological and political education autonomy. Besides, the integration provides a richer practice platform. Through a common, popularized and life-like mode, students will produce inner resonance in learning practice. Universities can make full use of theme music resources to carry out practical teaching, construct a new ideological and political education method. Forms like chorus can enhance attractiveness of ideological and political courses as well as promote its vividness and abundance.

\section{Predicament Confronted in the Integration of Theme Music into Ideological and Political Education in Universities}

Based on the characteristics of theme music, it has an inherent natural unity with ideological and political education in universities: both theme music and ideological and political education pursue a real, kind and good educational value; they both are of obvious political guidance; they both reflect motivate and leading functions of psychology and spirits. However, at the same time, the integration of theme music into ideological and political education in universities also confronts many problems that need urgent dealing:

Firstly, for a long time, theme music impresses the public with a rigid feeling. Especially in the mobile internet era, the rapid dissemination of information and diversified values result into students' incorrect cognition for theme music. They believe that the emotional spirits of theme music are inconsistent with the current time and society. Therefore, it is hard for students to accept the artistic form of theme music, or even be against it, neglecting its connotation. Because of students' lack of acceptance, theme music can not give a full play to its ideological and political education function.

Simultaneously, from the term of theme music's current application condition, most universities just organize music appreciation and students as well as teachers are not active at all. The integration of theme music neglects students orientation and fails to stress the fusion of employment, education and life, making students feel boring. In addition, its form is single, lacking efficient interaction and students' participation is low all of which reflect that the activities are just a kind of formality which aims to complete learning contents. So, the problem that how to take a effective method to guide correctly students to understand, recognize connotations and values of theme music is worth a further research and practice. [2]

Moreover, with the continuous development of mobile internet as well as global culture and values' conflict, students' thoughts tend to be more diversified. Under the impact of various cultural thoughts, students begin to lost their subjective consciousness and spirits, or even have distorted values and insufficient national consciousness. Besides, influences from personal heroism, utilitarianism and hedonism etc, as well as a lack of positive consideration and learning of theme music resources will inevitably impact the teaching effectiveness of integration of theme music into ideological and political education. 


\section{Methods to Integrate Theme Music into Ideological and Political Education in Universities}

Confronted with the current complicated information and cultural environment, it is suggested for universities to actively create theme music cultural atmosphere. Through various forms like theme music activities and theme music cultural education, students will improve their thoughts recognition. Specifically, it is advised for universities to set up "specialized windows" to learn theme music culture in university journal, website bulletin boards, campus micro-blog, WeChat platform and so on. This will be conducive to build campus culture of theme music and a good atmosphere of ideological and political education, both of which have pernicious effects. Simultaneously, it is advised to establish a theme music choir which will not only give a full play to students' artistic talents, but also build a strong theme music cultural atmosphere. The choir centers the singing of excellent theme music, pay attention to inherit and carry forward national spirits, praise beautiful lives, show positive spirits of universities and make students feel the revitalization of the nation, national development, confirmation of ideal faith as well as spiritual heritage. It is also feasible to establish red communities which aim to publicize theme songs, movies and carry out red investigation, visits as well as other activities. Taking the main platform of communities to construct the second classroom of ideological and political education is a good method to cultivate students' beliefs, moral qualities and legal concepts. In addition, we can set up elective courses of theme music. Through such courses, students will be leaded to know and get familiar with the contents and characteristics of theme music. Based on students' actual needs and internal as well as external factors, they can choose courses they are interested in. [3]

In ideological and political education practice, teachers should actively make use of theme music to reform the traditional classroom teaching mode which means that we need to solve the problem of boring education contents and single mode, then to explore contents and mode that attract students more easily. It is feasible to integrate theme music works related to classroom contents into ideological and political education. For example, when teaching Outline of History of Contemporary and Modern Chinese, we need to find theme music corresponding to the time background, then play it for students through multimedia and make them have a direct feeling. Based on these, teachers introduce the background of the music works in combination with classroom contents. In this way, ideological and political education contains music with strong appeal and the songs include stories as well as emotions, making teaching more attractive. At the same time, after practicing songs in class, we also need to organize students to share and communicate these after class, improving their ideological and political consciousness and moral quality. [4] After class, students are suggested to discover by themselves theme music that is related to ideological and political contents, analyze their creation background, contents as well as emotional expression and communicate with each other in the next class. Based on this way, we will turn students from passive learning into active exploration.

Rich extracurricular activities on campus will not only realize the goals of ideological and political education imperceptibly, but also relax students in learning and activities which will promote their autonomy and initiative. To carry out ideological and political activities centering on theme music, we should pay attention to the innovation of contents and mode, and keep pace with the times. For example, we can held campus concert centering theme music and organize campus bands to held singing competitions. When theme music works are throughout various kinds of music activities that students like, they will feel the artistic charm and inner emotion of theme music. Besides, we also can carry out "red song class singing" and small concerts. These will require all classes' participation, in which, students sing or do drama performance. based on theme music. According to the annual political hot spots, we can organize theme music chorus competitions, for example, To Commemorate the Victory of the Red Army in 80th Anniversary. The instructors can guide students to sing Ten Times' Farewell To Red Army and introduce related historical backgrounds, enhancing their understanding of revolution of red army.[5] At the same time, it is proposed to encourage the class to extend the connotation of songs in various ways. For example, to interweave chorus programs with dances reflecting revolution and scene plays showing class emotion will make the competition more attractive. 
In the mobile Internet era, problems that how to effectively apply Internet and discover the binding points between Internet and ideological and political education in universities are very important and worth our urgent exploration. Instructors and ideological and political teachers should strengthen the construction of theme music Internet platform, innovate talents cultivation mechanism of theme music songs, take advantage of new media platform to enhance communication between teachers and students, communities between communities,realizing dissemination and acceptation of ideological and political education connotations. For example, special column for appreciating theme music works can be set up through campus WeChat public platform and micro-blog etc. In the column, we can propagate and play theme music regularly, share related information and help students know excellent theme music with artistic and ideological qualities. Besides, we also can regularly propose Internet discussion topics in combination with social hot points. It is suggested to set up theme music communication and evaluation modules to guide teachers and students to discuss and explore excellent theme music works. Moreover, everyone is encouraged to choose excellent works and publicize them on new media platforms. In this way, Internet ideological and political education camp will be dominated by theme music which purifies campus Internet public opinions environment and promotes online as well as offline cooperation for ideological and political education.

\section{Conclusion}

In a word, theme music plays a vital role in ideological and political education. Confronted with new trends and so many problems, as ideological and political workers, we should take advantage of characteristics and merits of theme music to create a good theme music cultural atmosphere, innovate teaching modes, enrich ideological and political practices, give a full play to theme music' leading function, and promote the revolution and development of ideological and political education in further.

\section{References}

[1] Jiang Yuan. A Study of Red Songs' Functions in Ideological and Political Education in Universities [J]. Youthful Days, 2016(9):129-130.

[2] Yang Xiaohong. The Ideological and Political Functions of Red Classical Songs [J]. Journal of Yan'an Vocational \& Technical Institute, 2015(5):219.

[3] Dong Tiejun. A Study of Theme Film and Television Programs' Application in Ideological and Political Education [J]. Journal of Jiamusi Vocational Institute,2017(4):100-101.

[4] Hou Honglian. Influences of Theme Film and Television Programs' Carrier on Ideological and Political Theories Teaching Effects [J]. Journal of Chifeng University,2011(8):253-255.

[5] Jin Yuan, Tang Wenpeng. A Study of Teaching Methods Innovation of Ideological and Political Education in Universities in the New Era-from the Perspective of Theme Songs [J]. Journal of North University of China,2017(1):65-68. 